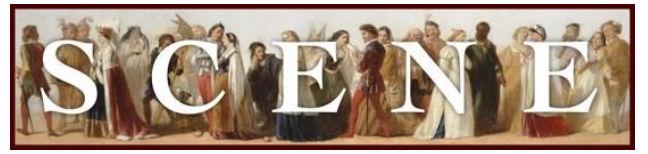

\title{
The Merry Wives of 1960 s Windsor, Ontario
}

\section{by Melissa Walter. Written on 2016-09-07. Published in 2017 Issue 2.}

For the production: The Merry Wives of Windsor (2016, Bard on the Beach, Canada). See production details at the end of the review.

JOHNNA WRIGHT'S ROLLICKING MERRY WIVES OF WINDSOR ROCKED THE MAINSTAGE OF THE Bard on the Beach Festival in Vancouver from June 17-September 24, 2016. Well-paced and wellperformed, the play portrayed a nostalgic view of small-town life, animated by a live countryand-western/rock-and-roll band, from the percussive descending bassline of "These Boots are Made for Walking" through the uplifting "Waltz Me Once Again Round the Dance Floor." The production layered Shakespeare over nostalgia for late 1960 s small-town Canada, associating Shakespeare with a particular vision of Canada's past.

The play is set in Windsor, Ontario, 1968. The back of the festival's Mainstage, which is sometimes open to reveal the lights of Vancouver's West End against the mountains, is filled in with a set showing the Garter Inn. It's open mic night. Taxidermy moose and deer heads preside, alongside a dartboard, Canadian and Ontarian flags, and a community message board. The lava lamp on the bar hints at the impending 1970s. Young couples, the women in sweater sets, are at the pub tables, and as the band comes together with fiddle, bass, and keyboards, they try out some dance steps. At one point, later on in the play, someone boldly says into the

mic, 'Evening Sudbury!' - the big city. And Falstaff (Ashley Wright) will be disguised as the Witch of Brantford, Ontario (though, as I found while checking into Ontarian cities, Brantford ON is named after Mohawk Chief Joseph Brant rather than the London suburb, Brentford.

The conceit of the open mic of course implies and enacts participation. The first to take up the open mic are Mistress Page (Katey Wright, in pink) and Mistress Ford (Amber Lewis, in blue). Tentative at first, they are soon belting out "These Boots are Made for Walking" and the audience settles into the rhythm. Director Johnna Wright's program note states that "To me, this play is built around an idea of community. The many 'misfits' - Falstaff included - are an integral part of that community and are lovingly mocked along with the rest. No one is exempt, yet in the end, everyone is accepted, warts and all. To me, this reflects, if not a reality of Canadian culture, at least a way I think we'd like it to be" (Bard on the Beach 2017 Program, 13). 
Indeed, the potential sting, in Canada, of the claim by Master Ford (Scott Bellis) claim that "I will never mistrust my wife again, till thou art able to woo her in good English" (5.5.132-133) received no emphasis in this lighthearted romp.

The audience is also brought into the community by music, well supported by a band including Fenton (Daniel Doheny) on drums, Bardolph (Victor Dolhai) on fiddle, Simple (Dawn Petten) on cello, and Slender (Ben Elliott) on keyboards. For instance, after Mistress Quickly (Jennifer Lines) brings Falstaff a bra to falsely imply that Mistress Ford loves him, and Falstaff sings to the bra "Girl, you're getting that look in your eyes," he then brings an audience member on stage and continues singing to her ("Baby, baby don't get hooked on me"). The disco lights start up and other cast members join in as backup singers, stepping rhythmically down the aisles of the big theatre, as disco lights incorporate audience and actors alike into the number.

The overall sense that the community is quietly laughing at itself-a form of gentle irony often considered typically Canadian-is echoed as well when various characters laugh at their own performances. Falstaff enjoys his own puns and speaks to his own reflection in a spoon, narcissism driven to a tiny limit. Mistress Ford sings "Crazy" to Falstaff's jacket, pretending she doesn't know he's watching, flirting with and physically abusing the jacket. She then laughs hilariously, aside. Ford's athletic vault out of the buck-basket appears as a form of physical irony responding to his hapless descent into the linens. In preparation for the forest scene, when Master Ford gets down the horns from the wall of the community pub and hands them to Falstaff, this too seems to highlight the community laughing at itself.

The broadly drawn characters also make comedy through exaggeration and nostalgic citation. Slender has an unbelievably goofy body posture, with knees and hips cartoonishly forward, lungs back; advanced as a suitor for Ann Page (Hailey Gillis), he is the hapless pawn of the grownups. It's Simple (an awkward girl who earnestly reads Shakespeare's sonnets as she curls her hair around her finger) that he really wants. Doctor Caius (Andrew Chown), outraged when someone hides in his Arne Jacobsen "chaise d'oeuf" (Egg chair), is an Anglophone stereotype of a French man, pursuing the latest in style and décor. He strikes poses and thrusts his rapier suggestively, creating a pink panther effect with his enthusiastic accent and carriage. His green velvet suit and overall panache fall into place when he is delighted to find himself married to a boy. (In the play's concluding musical number, Dr. Caius, now wearing a corset and bra, gyrated with serious, uncomic skill and verve, and waltzed a male audience member "once again round the dance floor"). Mistress Quickly, with her lacquered pink bouffant hair, pink round earrings, and pink pumps, dress, and apron, is a sexed-up Betty Crocker, or Joan Holloway from Mad Men. (Master Page [Tom Pickett] is a bit flirtatious towards Mistress Quickly, which seems unsurprising given her pink magnificence.) Fenton enters with the 
thumbs up Fonzie gesture ("He-e-e-ey") and his bad boy leather jacket recalls that hero of the 1970s sitcom Happy Days. Of course, Happy Days itself represented nostalgically the 1950 and ' 60 s in the US. Ann Page appears as a healthy teenager, checking out the postman from behind as he delivers a note from Fenton. In spite of the yellow sweater set, she manages to hint of Amy Winehouse with her high black hair and frank stage presence.

At one point Mistress Ford is in the yard in curlers and blue pedal pushers. A white picket fence, lawn chairs, and a pink flamingo complete the scene. The furniture is all white, and Mistress Quickly has her feather duster, but there seems to be little tension over the domestic economy of a 1950s suburban home. Mistress Quickly wears pink, as do the Page couple, while the Ford couple wears blue. Set five years after Betty Friedan wrote in The Feminine Mystique, "We can no longer ignore that voice within women that says: 'I want something more than my husband and my children and my home'," the play seems in this pointed privileging of "pink" to celebrate the wisdom, satisfaction, and role of the 1950 s housewife.

The play's emphasis on community warmth and the ability of a community to heal its wounds, for mockery to not go too far, for foibles to be tolerated, is lovely. Yet in highlighting conviviality, the production removes some of the class and gender tensions that the text articulates through Pistol's anger at being turned away from Falstaff's service and his subsequent retaliation. In Wright's play, Pistol is omitted, and when Falstaff turns away Bardolph, he becomes a tapster and is happy. Similarly, Mistresses Page and Ford do not seem much at risk from gossip-Mistress Ford is hurt by Master Ford's jealousy, but this is at a personal level. Master Page's advice to Master Ford that "If he should intend this voyage towards my wife, I would turn her lose to him" (2.1.165) seems well supported by the general mood. In spite of the fact that Ford drunkenly denounces Ms. Ford from the open mic by singing "Your Cheating Heart" directly to her, pushing against the overall good humor of the play, the onstage audience quickly and completely sees that Ford is in the wrong.

Disguised as Master Brook, Ford wears black, loose-fitting clothes, a beret, and a peace medallion necklace, and he describes his plight in a slow-jammed spoken word performance. After he drinks himself to sleep, the Host covers him with a Hudson's Bay blanket. Cat Stevens's "Morning Has Broken" signals a new day. The good-natured ridicule of Ford also spills onto his beatnik disguise, as Ford progresses to describing himself as "cuckold, cuckold," his hairs sticking up on top of his head like the crest of an angry bird. Ford really loses it when he becomes convinced that Falstaff is in the (dumpster-sized) buckbasket. By the time he shouts "My jealousy is reasonable," spit flying, he has gotten himself wrapped in linen as if in a straightjacket. The beatnik identity seems aberrational. 
Once Falstaff's machinations have been revealed, Mistress Ford is still mad at her husband, and it is music that brings her back into the community. Ford sings "Stand by your man," to her, the goofy mismatch of the opening lines, "Sometimes it's hard to be a woman," associated with the awkwardness of his character. When the song opens up to its chorus, Ford is singing to the audience, too, and some are singing along. This song has developed a layered set of associations in popular culture, American political culture, and in the conclusion of The Crying Game (Neil Jordan, 1992) when the transgender Dil (Jaye Davidson) stands by the IRA fighter Fergus (Stephen Rea). Yet the lines, "but if you love him, you'll forgive him," still do pressure Mistress Ford to accept the ill-treatment she has received, and by the end of the song the full musical weight of the community is behind Master Ford.

The taming of Falstaff occurs in a drugged-out forest (Doo be, or not doo be? offers the Host), where Bardolph, as a fairy, is doing yoga. A reprise of "These boots are made for walking" has gone slant, while Mistresses Ford and Page still show up in well-buttoned Western outfits. In addition to the time periods being evoked, was this a moment of Vancouver vs. Ontario? I wondered.

This performance invited a diverse Vancouver audience to enjoy, participate in, and laugh at a nostalgic vision of small-town Ontario life. It offered particular pleasures to audience members that could recognize the flag of Ontario, a Jimmy-Hendrix-type riff on "Oh Canada," an Arne Jacobsen Egg chair, curling team banners on movable barriers, a Hudson's Bay blanket, and similar cues, whether from lived experience in the twentieth century or not.

Melissa Walter is Associate Professor of English at the University of the Fraser Valley near Vancouver, Canada. She is currently editing The Two Gentlemen of Verona for Internet Shakespeare Editions, and coediting, with Dennis Britton, an essay collection on the topic of "Rethinking Shakespearean Source Study." She has published articles on early modern drama and prose, including on European novellas in England, The Dialogues in the English and Malaiane Languages and Fletcher's Island Princess, and works by Shakespeare, Middleton, Webster. She has reviewed dance and performance for plankmagazine.com as well as the ISE. She is completing a book on Shakespeare's comedies and the Renaissance novella in England. 


\section{Production Details}

\section{General}

Title

Year

Theater Company

Theaters

Start Date

End Date
The Merry Wives of Windsor

2016

Bard on the Beach

BMO Mainstage (Canada)

2016-06-17

2016-09-24

\section{Cast}

\begin{tabular}{|c|c|}
\hline SIR JOHN FALSTAFF & ASHLEY WRIGHT \\
\hline FENTON & DANIEL DOHENY \\
\hline Justice ROBERT SHALLOW & DAVID MARR \\
\hline ABRAHAM SLENDER & BEN ELLIOT \\
\hline FORD & SCOTT BELLIS \\
\hline William Page & BEN ELLIOT \\
\hline PASTOR EVANS & ANDREW MCNEE \\
\hline DOCTOR CAIUS & ANDREW CHOWN \\
\hline Host & ANTON LIPOVETSKY \\
\hline BARDOLPH & VICTOR DOLHAI \\
\hline SIMPLE & DaWn Petten \\
\hline AliCE Ford & AMBER LEWIS \\
\hline Mistress MARgaret PAgE & KATEY WRIGHT \\
\hline ANNE PAGE & HAILEy Gillis \\
\hline Mistress QUickly & JENNIFER LINES \\
\hline
\end{tabular}

\section{Creatives}

Director
Apprentice Director
Costume Designer
Set Designer
Lighting Designer
CHOREOGRAPHy
Fight CHOREOGRAPHER
Music
Props Designer

JOHNNA WRIGHT

ROHIT CHOKHANI

DREW FACEY

PAM JOHNSON

GeRALD King

VALERIE EASTON

NICHOLAS HARRISON

BEN ELLIOT

HEIDI WILKINSON 